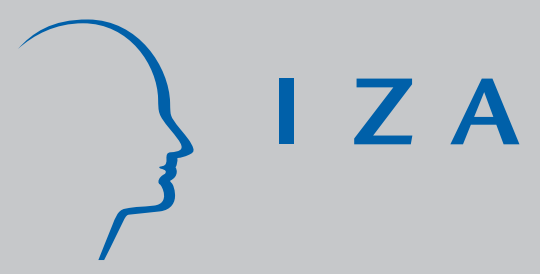

IZA DP No. 4020

Temporary J obs and J ob Search Effort in Europe

Lawrence M. Kahn

February 2009 


\title{
Temporary Jobs and Job Search Effort in Europe
}

\author{
Lawrence M. Kahn \\ Cornell University, CESifo, \\ NCER (Queensland) and IZA
}

Discussion Paper No. 4020

February 2009

\author{
IZA \\ P.O. Box 7240 \\ 53072 Bonn \\ Germany \\ Phone: +49-228-3894-0 \\ Fax: +49-228-3894-180 \\ E-mail: iza@iza.org
}

Any opinions expressed here are those of the author(s) and not those of IZA. Research published in this series may include views on policy, but the institute itself takes no institutional policy positions.

The Institute for the Study of Labor (IZA) in Bonn is a local and virtual international research center and a place of communication between science, politics and business. IZA is an independent nonprofit organization supported by Deutsche Post Foundation. The center is associated with the University of Bonn and offers a stimulating research environment through its international network, workshops and conferences, data service, project support, research visits and doctoral program. IZA engages in (i) original and internationally competitive research in all fields of labor economics, (ii) development of policy concepts, and (iii) dissemination of research results and concepts to the interested public.

IZA Discussion Papers often represent preliminary work and are circulated to encourage discussion. Citation of such a paper should account for its provisional character. A revised version may be available directly from the author. 
IZA Discussion Paper No. 4020

February 2009

\section{ABSTRACT}

\section{Temporary Jobs and Job Search Effort in Europe}

Using longitudinal data on individuals from the European Community Household Panel (ECHP) for eight countries during 1995-2001, I investigate temporary job contract duration and job search effort. The countries are Belgium, Denmark, Finland, France, Italy, the Netherlands, Portugal and Spain. I construct a search model for workers in temporary jobs which predicts that shorter duration raises search intensity. Calibration of the model to the ECHP data implies that at least 59\% of the increase in search intensity over the life a long term temporary job occurs in the last period. I then estimate regression models for search effort that control for human capital, pay, local unemployment, gender, and time and country fixed effects, I find that workers on temporary jobs indeed search harder than those on permanent jobs. Moreover, search intensity increases as temporary job duration falls, and at least $80 \%$ of this increase occurs on average in the shortest duration jobs. These results are robust to disaggregation by gender and country and to individual fixed effects. These empirical results are noteworthy, since it is not necessary to assume myopia or hyperbolic discounting in order to explain them, although the data clearly also do not rule out such explanations.

JEL Classification: J21, J23

Keywords: job search, temporary jobs

Corresponding author:

Lawrence M. Kahn

Cornell University

362 Ives Hall East

Ithaca, New York 14583

USA

E-mail: Imk12@cornell.edu

\footnotetext{
* Preliminary draft. Comments welcome. The author thanks Daniele Paserman for helpful discussion and Alison Davies and Rhys Powell for their aid in acquiring the European Labour Force Survey regional unemployment rate data. This paper uses European Community Household Panel data (Users Database, waves 1-8, version of December 2003), supplied courtesy of the European Commission, Eurostat. Data are obtainable by application to Eurostat, which has no responsibility for the results and conclusions of this paper.
} 


\section{Introduction}

A considerable volume of economic research has been devoted over the last two decades to explaining and suggesting remedies for the stubbornly high unemployment rates in a number of European countries. Among the suggested policy remedies for reducing joblessness is the relaxation of systems of employment protection by allowing firms greater freedom to create temporary jobs. These reforms presumably reflect a desire to maintain protections for workers in permanent jobs while giving firms an incentive to create new, temporary jobs, which may ultimately become permanent. However, such policies may instead encourage firms to substitute temporary for permanent jobs (as found by Kahn 2007a), and, if so, the overall exit rate from jobs may increase. The resulting higher turnover may even lead to higher equilibrium unemployment than before (Blanchard and Landier 2002; Cahuc and Postel-Vinay 2002). Moreover, temporary jobs are known to pay less, offer less training, and be less satisfying than regular jobs (Booth, Francesconi and Frank 2002; Kahn 2007b). Thus, reforms that encourage the creation of temporary jobs may not lower unemployment and also may not unambiguously raise employed workers' utility (Blanchard and Landier 2002; Cahuc and Postel-Vinay 2002).

Policy evaluations of reforms that encourage temporary jobs must take into account the degree to which they become stepping stones to higher paying, permanent jobs. And evidence on this question of whether temporary jobs are stepping stones to permanent jobs is mixed (Booth, Francesconi and Frank 2002; Autor and Houseman 2005). If workers are indeed seemingly trapped in temporary jobs, this outcome could have resulted either due to the lack of availability of permanent jobs or insufficient search effort on the part of workers. Of course, a greater supply of permanent jobs is likely to encourage greater search effort. But little is known about the search effort of those currently in temporary jobs. For example, do they anticipate the end of those jobs and begin searching in advance for future work, or do they wait until the last minute to begin their job search? A similar set of questions has been asked about unemployed workers whose unemployment insurance (UI) benefits are about to expire (Katz and Meyer 
1990; Mortensen 1990). The answers to these questions can have important implications for the transition from temporary to permanent jobs and therefore for evaluations of policies that allow firms to create temporary jobs.

In this paper, I use European Community Household Panel (ECHP) data to study the job search behavior of workers employed in temporary jobs in several European countries over the 1995-2001 period. The countries included are Belgium, Denmark, Finland, France, Italy, the Netherlands, Portugal and Spain. The ECHP collects information on current job search effort among employed workers (as well as of course the unemployed). In addition, the surveys include data on the duration of one's employment contract if it is temporary, allowing one to determine the impact of contract duration on search effort. I first build a simple model of employed job search that draws from search models in Burdett (1979) and Mortensen (1990). A key theoretical result is that the less time left on a temporary contract, the greater is one's search effort, a result that is not surprising. However, calibration of the model using observed transition rates to permanent work and to temporary work implies that at least $59 \%$ of the increase in search intensity over the life a temporary contract occurs in the last period of the employment contract. It is noteworthy that this result is obtained without assuming hyperbolic discounting or myopia on the workers' part, although it is also of course consistent with such behavior (see, for example, DellaVigna and Paserman 2005 or Paserman 2008). This result is similar to Mortensen's (1990) theoretical result that almost all of the reduction in an unemployed searcher's reservation wage occurs in the period before his/her unemployment benefits expire, a finding that is supported by Katz and Meyer's (1990) study of unemployed searchers in the United States.

I then estimate the impact of contract duration on search effort as measured in the ECHP data base. In general, those on temporary contracts search harder than those in permanent jobs, as one would expect. And search intensity increases going from the longest to the shortest duration temporary contracts, again as one would predict. Moreover, almost all of the increase in search intensity going from longest to shortest duration jobs occurs between the second shortest 
(6-12 months) and the shortest (less than 6 months) duration jobs, as predicted by the calibrated Burdett-Mortensen model. This finding occurs in data pooled across countries as well as within countries analyzed individually. And this result holds up in models that use the longitudinal feature of the ECHP and control for individual fixed effects, suggesting that it is not merely due to a correlation between an individual's fixed search propensity and likelihood of landing a long duration job. These results also hold for men and women analyzed separately, further implying that they are pervasive in European labor markets.

It thus appears that workers are indeed forward-looking in their job search behavior; however, the optimizing strategy is to not start searching intensively early in the term of one's temporary job, like that of unemployed workers with limited duration unemployment benefits. Some countries have reformed their regulations of temporary employment contracts by increasing their allowable duration (OECD 2004). An implication of the results obtained here is that such policies will reduce the average search intensity of workers on temporary jobs, perhaps lessening the ultimate transition rate to a permanent job.

\section{A Simple Model of Temporary Jobs and Search Intensity}

In this section, I write down a simple model that sheds some light on the impact of a temporary contract's remaining duration on the employed worker's search intensity. Like earlier models of search intensity such as Della Vigna and Paserman (2005) and Paserman (2008), I use a discrete time framework and assume that a jobseeker will receive a wage offer with some

probability in any given period. Moreover, one can raise this probability by searching harder and this increased search effort (e.g. putting in more time or money to the search effort) will be costly. I allow the new job offer to be either a permanent job or a temporary job, although the jobseeker doesn't know in advance what kind of job if any will be offered by a contacted firm. 
To simplify the analysis, I assume that permanent jobs never end and temporary jobs last T periods. ${ }^{1}$

Let $\lambda$ be the probability of receiving a permanent job offer and assume that the probability of receiving a temporary job offer is a $\lambda$, where a>0; following Mortensen (1990), assume that one can receive at most one job offer per period. I assume that the job seeker can affect $\lambda$ at search cost $c(\lambda)$, and that search costs are quadratic:

(1) $\mathrm{c}(\lambda)=.5 \lambda^{2} \cdot$

Thus, by investing more resources in search costs, the job seeker raises the probability of receiving a permanent or a temporary job offer, and I make no assumptions about the relative probabilities of the two types of job offer. I only assume that greater search effort raises each probability. As in basic job search models such as those in Mortensen (1990), let the following value functions refer, respectively, the present value of being employed in a permanent job $(\mathrm{W}()$.$) , in a temporary job with \mathrm{n}$ periods remaining $\left(\mathrm{V}_{\mathrm{n}}().\right)$, or as an unemployed jobseeker $\left(\mathrm{V}_{0}\right)$, where the argument in the case of employees is the wage offer. Wages within a job are assumed constant, for convenience. Let $\mathrm{B}$ be the discount factor (i.e. $\mathrm{B}=1 /(1+\mathrm{r})$ where $\mathrm{r}$ is the discount rate). Further, let $\mathrm{b}$ be the value of unemployment benefits, and assume that search is no more efficient while unemployed than while employed in a temporary job. ${ }^{3}$

It can be shown that the jobseeker will in all cases follow a reservation wage policy. However, because the value of a wage offer $\mathrm{x}$ in a permanent job is different from the value of a temporary wage offer of $\mathrm{x}$, the jobseeker may select a different reservation wage for permanent offers than for temporary offers. Therefore, let $\mathrm{R}_{0}$, and $\mathrm{R}_{\mathrm{n}}(\mathrm{w})$ be the reservation wages for

\footnotetext{
1 These assumptions are not necessary for the results below but are made for convenience.

2 These assumptions for search costs and the probability of an offer are made for convenience and are innocuous since we can parameterize search costs appropriately.

3 The model could easily be modified to allow different probabilities of receiving a permanent or temporary job offer while employed than while unemployed, as in Mortensen's (1990) model of workers awaiting recall. But the basic features would remain the same as in the simpler version presented here.
} 
permanent job offers facing, respectively, unemployed searchers, and temporary job holders with $n$ periods remaining in their temporary jobs, which are assumed to pay wage $w$; let $T_{0}$ and $T_{n}(w)$ be the corresponding reservation wages for temporary job offers.

We may now analyze the value functions for jobseekers in different situations. First, the value of being unemployed is:

(2) $V_{0}=b+B \lambda_{0} E\left[\operatorname{Max}\left(W(x), V_{0}\right]+B a \lambda_{0} E\left[\operatorname{Max}\left(V_{T}(x), V_{0}\right]+B\left(1-\lambda_{0}-a \lambda_{0}\right) V_{0}-\right.\right.$ $.5\left(\lambda_{0}\right)^{2}$,

where the expectation in each case is taken with respect to the distribution of permanent or temporary job wage offers $\mathrm{x}$ given an offer.

Equation (2) states that the present value of being unemployed equals the current unemployment benefit $b$ plus the expected discounted value of future labor market states minus current search costs. In the next period, there are three possible job offer outcomes: one can have received a permanent job offer (with endogenous probability $\lambda_{0}$ ), a temporary job offer (with probability $\mathrm{a} \lambda_{0}$ ), or one can have not received any offers (with probability $1-\lambda_{0}-\mathrm{a} \lambda_{0}$ ). If one has received a job offer of either type, one then needs to decide whether to accept it by comparing the value of accepting it with the value of continuing unemployment. Thus, in any period, the searcher has three choices: a search intensity and reservation wages for permanent or temporary job offers.

Equation (2) can be simplified by using the reservation wage property:

(3) $V_{0}=b+B \lambda_{0} \int_{\mathrm{R} 0}^{\infty}\left[W(x)-V_{0}\right] d F(x)+B a \lambda_{0} \int_{\mathrm{T}_{0}}^{\infty}\left[V_{T}(y)-V_{0}\right] d G(y)+B V_{0}-.5\left(\lambda_{0}\right)^{2}$, where $\mathrm{F}($.$) and \mathrm{G}($.$) are respectively the distribution functions for wage offers in permanent and$ in temporary jobs.

The reservation wages $\mathrm{R}_{0}$ and $\mathrm{T}_{0}$ each solve the following equations: (4) $\mathrm{W}\left(\mathrm{R}_{0}\right)=\mathrm{V}_{0}$ 
(5) $\mathrm{V}_{\mathrm{T}}\left(\mathrm{T}_{0}\right)=\mathrm{V}_{0}$.

In other words, the reservation wages for each type of offer are set so as to make the searcher indifferent between continued search and accepting the job.

Search effort $\lambda_{0}$ can be calculated by maximizing (3) with respect to $\lambda_{0}$. Assuming an interior solution, we have:

(6) $\lambda_{0}=B \int_{\mathrm{R} 0}^{\infty}\left[W(x)-V_{0}\right] d F(x)+B a \int_{\mathrm{T} 0}^{\infty}\left[V_{T}(y)-V_{0}\right] d G(y)$.

Search effort is positively affected by the expected gains to an accepted job offer.

To study the behavior of search effort in temporary jobs of various remaining duration levels, I now write down the value functions for being in a temporary job with one, or $\mathrm{n}$ remaining periods. First, for those with one period remaining in their temporary job, which is assumed to pay a wage w, we have:

(7) $V_{1}(w)=w+B \lambda_{1}(w) \int_{\mathrm{R} 1(\mathrm{w})}^{\infty}\left[W(x)-V_{0}\right] d F(x)+B a \lambda_{1}(w) \int_{\mathrm{T} 1(\mathrm{w})}^{\infty}\left[V_{T}(y)-V_{0}\right] d G(y)+$ $B V_{0}-.5\left(\lambda_{1}(w)\right)^{2}$,

where a 1 subscript on the value function, reservation wages and search intensity refers to the time remaining on the current temporary job. Since the current job will end in the next period, the value of turning down a job offer or not receiving a job offer is the same as it was for the unemployed searcher. ${ }^{4}$ Therefore, the reservation wages are the same in the last period of employment as they are for the unemployed searcher. By implication, so is the optimal search intensity $\lambda_{1}(\mathrm{w})$. Period 1 reservation wages and search intensity are therefore independent of the current wage. Being employed in a temporary job with one period left therefore has a value that

\footnotetext{
${ }^{4}$ Note that I have assumed that the probability of obtaining a permanent or temporary job offer given search effort is the same whether or not one is currently employed. Below, I discuss the likely consequences of relaxing this assumption.
} 
is equal to the value of being unemployed plus (w-b). On the assumption of indefinite duration of unemployment benefits, then, workers only accept jobs paying at least $b$.

The goal of this model is to provide insight into the behavior of search intensity as the end of one's temporary job approaches. I now therefore show the value function for being in a temporary job with n periods remaining:

$$
\begin{aligned}
& V_{n}(w)= \\
& w+B \lambda_{n}(w) \int_{\mathrm{Rn}(\mathrm{w})}^{\infty}\left[W(x)-V_{n-1}(w)\right] d F(x)+B a \lambda_{n}(w) \int_{\mathrm{Tn}(\mathrm{w})}^{\infty}\left[V_{T}(y)-V_{n-1}(w)\right] d G(y)+ \\
& B V_{n-1}(w)-.5\left(\lambda_{n}(w)\right)^{2} .
\end{aligned}
$$

where as before, the subscripts refer to the number of periods remaining in the temporary job.

Using the same logic as above, we can say that reservation wages for the various time periods and job offers satisfy:

(9) $\mathrm{W}\left(\mathrm{R}_{2}(\mathrm{w})\right)=\mathrm{V}_{1}(\mathrm{w})=\mathrm{V}_{0}+\mathrm{w}-\mathrm{b}>\mathrm{V}_{0}$ for all jobs paying wages strictly greater than UI benefit levels

(10) $\mathrm{W}\left(\mathrm{R}_{\mathrm{n}}(\mathrm{w})\right)=\mathrm{V}_{\mathrm{n}-1}(\mathrm{w})>\mathrm{V}_{\mathrm{n}-2}(\mathrm{w})$ for all jobs paying wages strictly greater than UI benefit levels (because a promise of $\mathrm{n}-1$ periods at a wage greater than UI benefits is worth strictly more than a promise of $n-2$ periods of the same wage).

Equations (9) and (10) show that the reservation wage falls as the time remaining in one's temporary job rises. Once a worker is employed at wage w, the unemployment benefit to which he/she would be entitled in the event of layoff would likely be strictly less than the current wage, given less than $100 \%$ replacement ratios (Nickell and Layard 1999). The following solutions for $\lambda_{2}(\mathrm{w})$ and $\lambda_{\mathrm{n}}(\mathrm{w})$ for $\mathrm{n}>2$ show that optimal search intensity rises over time:

(11) $\lambda_{2}(\mathrm{w})=B \int_{\mathrm{R} 2(\mathrm{w})}^{\infty}\left[W(x)-V_{1}(w)\right] d F(x)+B a \int_{\mathrm{T} 2(\mathrm{w})}^{\infty}\left[V_{T}(y)-V_{1}(w)\right] d G(y)$ 
(12) $\lambda_{\mathrm{n}}(w)=B \int_{\mathrm{Rn}(\mathrm{w})}^{\infty}\left[W(x)-V_{n-1}(w)\right] d F(x)+B a \int_{\mathrm{Tn}(\mathrm{w})}^{\infty}\left[V_{T}(y)-V_{n-1}(w)\right] d G(y)$.

Since reservation wages fall over time as does the value of remaining employed in one's current temporary job, search intensity rises. We are now in a position to place some bounds on the speed with which search intensity rises.

By the properties of the reservation wage, we have:

(13) $\lambda_{\mathrm{n}+1}(w)>B \int_{\mathrm{Rn}(\mathrm{w})}^{\infty}\left[W(x)-V_{n}(w)\right] d F(x)+B a \int_{\mathrm{Tn}(\mathrm{w})}^{\infty}\left[V_{T}(y)-V_{n}(w)\right] d G(y)$.

Inequality (13) holds because a) for all values of the permanent wage offer $\mathrm{x}$ less than $R_{n+1}(w), W(x)<V_{n}(w)$ and for all values of the temporary wage offer y less than $T_{n+1}(w)$, $\mathrm{V}_{\mathrm{n}+1}(\mathrm{y})<\mathrm{V}_{\mathrm{n}}(\mathrm{w}) .^{5}$ Therefore, by equation (12) and expression (13), we have:

(14)

$0<\lambda_{\mathrm{n}}(\mathrm{w})-\lambda_{\mathrm{n}+1}(\mathrm{w})<\mathrm{B}\left(\mathrm{V}_{\mathrm{n}}(\mathrm{w})-\mathrm{V}_{\mathrm{n}-1}(\mathrm{w})\right)\left(1-\mathrm{F}\left(\mathrm{R}_{\mathrm{n}}(\mathrm{w})\right)+\mathrm{Ba}\left(\mathrm{V}_{\mathrm{n}}(\mathrm{w})-\mathrm{V}_{\mathrm{n}-1}(\mathrm{w})\right)\left(1-\mathrm{G}\left(\mathrm{T}_{\mathrm{n}}(\mathrm{w})\right)\right.\right.$.

By the same reasoning that led to expression (13), we have:

(15) $\lambda_{\mathrm{n}-1}(w)>B \int_{\mathrm{Rn}(\mathrm{w})}^{\infty}\left[W(x)-V_{n-2}(w)\right] d F(x)+B a \int_{\operatorname{Tn}(\mathrm{w})}^{\infty}\left[V_{T}(y)-V_{n-2}(w)\right] d G(y)$

Therefore, (16) $\lambda_{\mathrm{n}-1}(\mathrm{w})-\lambda_{\mathrm{n}}(\mathrm{w})>\mathrm{B}\left(\mathrm{V}_{\mathrm{n}-1}(\mathrm{w})-\mathrm{V}_{\mathrm{n}-2}(\mathrm{w})\right)\left(1-\mathrm{F}\left(\mathrm{R}_{\mathrm{n}}(\mathrm{w})\right)+\mathrm{Ba}\left(\mathrm{V}_{\mathrm{n}-1}(\mathrm{w})-\mathrm{V}_{\mathrm{n}-2}(\mathrm{w})\right)\left(1-\mathrm{G}\left(\mathrm{T}_{\mathrm{n}}(\mathrm{w})\right)\right.\right.$.

Using inequalities (14) and (16), we can bound the relative increase between periods $n+1$ and $n$ versus periods $n$ and $n-1$ (with the period numbers referring to time left in the temporary job) in the jobseeker's search intensity:

\footnotetext{
5 These inequalities therefore hold for all wages between $R_{n}$ and $R_{n+1}$ and $T_{n}$ and $T_{n+1}$, since $R_{n}<R_{n+1}$ and $T_{n}<T_{n+1}$.
} 
The maximum value of being employed at wage $w$ in a temporary job with $n-1$ periods left must be greater than the value of choosing the period $n$ reservation wages and search intensity (assuming a unique reservation wage):

$V_{n-1}(w)>$

$w+B \lambda_{n}(w) \int_{\mathrm{Rn}(\mathrm{w})}^{\infty}\left[W(x)-V_{n-2}(w)\right] d F(x)+B a \lambda_{n}(w) \int_{\mathrm{Tn}(\mathrm{w})}^{\infty}\left[V_{T}(y)-V_{n-2}(w)\right] d G(y)+$ $B V_{n-2}-.5\left(\lambda_{n}(w)\right)^{2}$.

Therefore, using equation (16) and inequalities (17) and (18), we have:

$$
\begin{aligned}
& {\left[\lambda_{n}(w)-\lambda_{n+1}(w)\right] /\left[\lambda_{n-1}(w)-\lambda_{n}(w)\right]<\left[V_{n}(w)-V_{n-1}(w)\right] /\left[V_{n-1}(w)-V_{n-2}(w)\right]<} \\
& \quad \text { B }\left\{1-\lambda_{n}(w)\left(1-F\left(R_{n}(w)+a-a G\left(T_{n}(w)\right)\right\} .\right.\right.
\end{aligned}
$$

According to expression (19), the increase in search intensity between periods $n+1$ and $n$ relative to the increase between periods $n$ and $n-1$ is less than the discount factor times the probability of not finding either an acceptable new permanent job or acceptable new temporary job in period n. Since finding an acceptable new permanent job or an acceptable temporary job are mutually exclusive events, one minus the sum of their individual probabilities is the probability of not moving, abstracting from the possibility of quitting to drop out of the labor force or search while unemployed. Let $\mathrm{E}_{\mathrm{n}}$ be the probability of not moving (i.e., $\left\{1-\lambda_{n}(w)\left(1-F\left(R_{n}(w)+a-a G\left(T_{n}(w)\right)\right\}\right)\right.$. Then,

(20) $\left[\lambda_{n}(w)-\lambda_{n+1}(w)\right] /\left[\lambda_{n-1}(w)-\lambda_{n}(w)\right]<B E_{n}$. 
We would like an estimate of the increase in search intensity in the last period (i.e. $\left.\lambda_{2}(\mathrm{w})-\lambda_{1}(\mathrm{w})\right)$ relative to the total increase in search intensity over the life of a temporary job (i.e. $\left.\lambda_{T}(\mathrm{w})-\lambda_{1}(\mathrm{w})\right)$. To estimate this relative increase, write $\left(\lambda_{T}(\mathrm{w})-\lambda_{1}(\mathrm{w})\right)$ as:

(21) $\left.\left.\left(\lambda_{\mathrm{T}}(\mathrm{w})-\lambda_{1}(\mathrm{w})\right)=\left(\lambda_{\mathrm{T}}(\mathrm{w})-\lambda_{\mathrm{T}-1}(\mathrm{w})\right)\right)+\left(\lambda_{\mathrm{T}-1}(\mathrm{w})-\lambda_{\mathrm{T}-2}(\mathrm{w})\right)\right)+\ldots+\left(\lambda_{2}(\mathrm{w})-\lambda_{1}(\mathrm{w})\right)$.

Then with successive use of inequality (20), we have:

(22) $\left(\lambda_{\mathrm{T}}(\mathrm{w})-\lambda_{1}(\mathrm{w})\right)<\left(\lambda_{2}(\mathrm{w})-\lambda_{1}(\mathrm{w})\right)\left(1+\mathrm{BE}_{3}+\mathrm{B}^{2} \mathrm{E}_{3} \mathrm{E}_{4}++\mathrm{B}^{\mathrm{T}-2}\left(\mathrm{E}_{3} \mathrm{E}_{4} \ldots \mathrm{E}_{\mathrm{T}}\right)\right)$.

While the ECHP data aren't fine enough to allow one to follow people within their temporary jobs, we can use the data to compare people with different total temporary contract durations or the same person in different jobs with different total durations. For example, a randomly chosen person with a 2 year contract will have on average one year remaining, while a randomly chosen person with a 6 month contract will have an average of 3 months remaining. Thus, comparing people under different contracts will be similar to comparing people with different amounts of time remaining on their temporary job, as the model depicts. As shown below, in the ECHP data, the potential durations of temporary jobs are defined in four categories with enough observations on which to perform meaningful statistical analyses: under 6 months; 6 months to under a year; one year to under two years; and two years or more. This division of the data by the ECHP suggests considering a period to be 6 months and therefore that $\mathrm{T}=5$. That is, period 1 is the less than 6 months category. Increasing by 6 month increments, we arrive at period 5, which is duration 2 to 2.5 years, or the highest category: period 2 is 6-12 months, period 3 is $12-18$ months, period 4 is $18-24$ months, and period 5 is $24+$ months. This means that we need to use the following limit for the total increase in search intensity relative to the increase in the last period: 
However, periods 3 and 4 (12-18 months) and (18-24 months) are aggregated by the ECHP, so we must set $\mathrm{E}_{3}=\mathrm{E}_{4}$.

Appendix Table A1 shows transition rates from temporary jobs of various total duration levels. If we make the maintained hypothesis that differences in behavior across durations are the same as that for an individual as the time left in his/her temporary job falls, then we use these transition rates to compute $\mathrm{E}_{3}, \mathrm{E}_{4}$, and $\mathrm{E}_{5}$ ). The data in Table $\mathrm{A} 1$ imply that $\mathrm{E}_{3}$ (and therefore $\mathrm{E}_{4}$ ) is 0.465 (i.e., 1-.057-.478) and $\mathrm{E}_{5}$ is .334 (i.e., 1-.066-.600). ${ }^{6}$ Using a discount factor $\mathrm{B}$ of 0.95 , inequality (23) implies that at least $59 \%$ of the total increase in job search intensity going from the longest to the shortest duration temporary job should occur in the last period. We therefore expect to see sharply increasing job search intensity as temporary job durations fall. This result does not assume myopia or hyperbolic discounting; however, we do predict rising search intensity throughout one's employment in a temporary job. If jobseekers are completely unresponsive to changes in the duration of their jobs, then we would conclude that they are myopic.

The model just outlined assumes that one's probability of a job offer given search effort is the same regardless of whether one is employed or unemployed. In reality, some temporary job contracts are renewed when they expire, and firms promote some workers from temporary jobs into permanent jobs. If such promotions or renewals are most likely in the last period of a temporary job, then the worker may be able to transition to a new temporary or permanent contract with his/her incumbent firm with little or no search effort. These considerations would reduce the difference in search intensity between the last period and earlier periods. On the other

\footnotetext{
${ }^{6}$ The total transition rate is actually somewhat higher for the longest duration temporary jobs than for the other categories, even though the search model predicts an increasing rate as the duration falls. The rate is higher for the $<6$ and 6-12 month categories than for the 12-24 month duration jobs, as search theory would predict. It is possible that the respondents in the different duration temporary jobs differ in measurable or unmeasurable ways that could affect their transition probabilities. The empirical work below controls for measured factors as well as personspecific unmeasured factors that would affect search intensity.
} 
hand, searching and generating an outside permanent job offer may lead one's current firm to offer a similar job by transforming the temporary contract into a permanent one. Therefore, some within firm transitions from temporary to permanent contracts may be the result of the kind of on the job search the ECHP measures. Finally, if search is more efficient while unemployed, then this would reduce the gap between $V_{1}(w)$ and $V_{0}$, again reducing the rate at which search intensity rises with time in one's temporary job.

\section{Data and Descriptive Patterns}

I use the ECHP data for 1995-2001 for the following countries to study the impact of temporary employment contracts on job search: Belgium, Denmark, Finland, France, Italy, the Netherlands, Portugal, and Spain. This is a panel data base that follows individuals over the 1994-2001 period. The questions were harmonized as much as possible in order to produce a data base that would provide comparable information across countries. ${ }^{7}$ Beginning in 1995 for all of these countries except Finland and in 1996 for Finland, the ECHP asked each employed wage and salary worker whether his/her job was characterized by a fixed term contract. Specifically, each employed respondent is asked: "What type of employment contract do you have in your main job?" The possible responses are: 1) permanent employment; 2) fixed-term or short-term contract; 3) casual work or no contract; 4) some other working arrangement. For the purposes of analyzing the determinants of temporary employment, I include only those with responses 1) or 2), that is, those that state they have a permanent or a temporary employment contract. Respondents with a temporary contract were asked how long the total duration of their contract was, with possible responses: less than 6 months, 6 months to less than a year, 1 year to under 2 years, 2 years to under 5 years, 5 years or more.

\footnotetext{
${ }^{7}$ For further description of the methods and sample characteristics of the ECHP, see the Eurostat web site: http://circa.europa.eu/irc/dsis/echpanel/info/data/information.html .
} 
To gauge on the job search activity, I use two questions from the ECHP. First, I use responses to the question asking employed workers whether they are looking for a job. Second, the ECHP asks whether in the last four weeks, a respondent has taken active steps to find a job. Examples given by the survey include: "contacted a public employment office,..., applied to an employer, studied or replied to advertisements, contacted a private employment or vocational guidance agency, asked friends or contacts, or taken steps to start your own business" (ECHP codebook, p. 273). In the empirical work below, I examine responses to both questions. The second question (about taking active steps) is more closely related to search effort than the first one, although the results were very similar for either measure of on the job search activity.

Tables 1-4 provide some descriptive information about contract duration and search activity. All statistics are weighted using the ECHP's provided person weights, and these have been adjusted in the data pooled across countries so that each country receives the same weight. Included in the tables are all employed workers with complete data on the explanatory variables used below and who have either a known fixed contract duration or a permanent job. The age range is restricted to $16-65$ years. Table 1 provides these data aggregated across the eight countries listed above. About $10 \%$ of the sample has a temporary contract, and the most common duration is 6-12 months (about $44 \%$ of temporary jobs), followed by less than 6 months (26\%), and 1-2 years $(21 \%){ }^{8}$ A very small fraction have 5 years or more duration $(3 \%)$. The incidence of on the job search and active search behavior look at first blush to be consistent with the theoretical model outlined earlier. First looking at the figures for on the job search, the fraction of workers searching rises from 0.082 of those in permanent jobs to 0.158 for those with at least two years' duration on a temporary contract. ${ }^{9}$ This figure rises again to 0.179 for those with 6 months to two years duration, and rises sharply to 0.291 for those with the shortest

\footnotetext{
${ }^{8}$ Earlier work has shown that the ECHP data on the incidence of temporary employment contracts match up well with published sources such as the OECD. See Kahn (2007a).

${ }^{9}$ In the empirical work, I will be aggregating the 2-5 years and 5 years plus categories because of the small numbers of cases in the later duration category. Table 1 shows that while these categories differ by about 3 percentage points in the incidence of job search, they are nearly identical in the incidence of active search behavior, a measure that is closer to the concept of search intensity.
} 
contract duration (under 6 months). In other words, the incidence of search activity rises by 20.9 percentage points between those with permanent jobs and those with the shortest temporary jobs, and 11.2 percentage points of this rise occurs between the $6-12$ months duration and $<6$ months duration categories. Moreover, among those with temporary contracts, search incidence rises by 13.3 percentage points from the $2+$ years category to the shortest category, with, as just noted, 11.2 percentage points or $84 \%$ of the rise occurring in between the two shortest duration categories.

Table 1's figures for search intensity (the incidence of active search behavior) are very similar to those for the incidence of job search. $5.2 \%$ of those on permanent contracts have engaged in active search behavior in the last four weeks (compared the $8.2 \%$ who said they were looking for a new job), a figure that rises to $11.4 \%$ for those with temporary jobs with at least two years' duration and finally to $23.0 \%$ of those on the shortest temporary contracts. Again, for those on temporary contracts, $84 \%$ of the increase in search intensity between the longest and the shortest temporary contracts occurs between the two shortest duration categories. But there is still a slight increase in search intensity from the 2+years category to the 6-12 months duration category.

Overall, then, workers appear to be forward-looking in the sense that the shorter one's employment contract, the more likely one is to search and the more intensively one searches. But most of the increase in search activity occurs for those in the shortest duration category. This result is especially noteworthy because the difference in expected duration between the two shortest categories is only 6 months (assuming a uniform distribution of actual durations within each category, the $<6$ months category averages 3 months, while the 6-12 month category has a mean 9 months duration), while it is at least a year between the other pairs of adjacent temporary job duration categories. This set of outcomes is precisely what is predicted by the search model outlined earlier. Tables 2-4 examine whether this pattern is common to each of the countries individually. Table 2 shows that for all of the countries except the Netherlands, the 6-12 months duration category is the most common temporary duration, while the least common is usually the 
$2+$ years duration jobs. Tables 3 and 4 show a remarkable consistency across countries in the incidence and intensity of job search in the various employment contract duration categories. In each case, those in permanent jobs are least likely to search or have the least amount of search activity, while those in the shortest temporary jobs search the hardest (Table 4). In addition, in most cases the largest increase in search activity among the temporary job holders occurs between the 6-12 months and the less than 6 months duration categories.

\section{Empirical Procedures and Regression Results}

Tables 3 and 4 show that search behavior in each country is consistent with the model discussed earlier, which of course did not assume myopia or hyperbolic discounting. In the empirical work that follows, I test whether these patterns hold up controlling for worker human capital, pay or economic conditions, as well as individual worker fixed effects. For example, it is possible that the shortest duration jobs pay lower wages than longer duration temporary jobs, and these purportedly lower wages could in principle explain the patterns in Tables 1, 3 and 4.

The basic empirical setup for testing the job search model presented earlier is to estimate the intensity of search as a function of contract duration and control variables:

(24) Active Search=f(dur0-6, dur6-12, dur12-24, dur24+, X, u),

where for each employed individual, Active Search is a dummy variable for having taken active measures to find a job in the last four weeks, dur0-6, dur6-12, dur12-14, dur24+ are dummy variables for being a temporary job with respective, less than 6 months, over 6 but less than 12 months, over 12 but less than 24 months, and at least 24 months total duration, $\mathrm{X}$ is a vector of control variables to be discussed below, and $\mathrm{u}$ is a disturbance term. 
In equation (24), the dependent variable is the ECHP's proxy for search intensity, although I also estimated models with an employed search dummy variable as dependent variable, with very similar results to those presented below. The duration variables correspond to the categories in Tables 2-4, and the omitted category is those who have permanent jobs. While, as noted earlier, the duration variables refer to total contract length, the person's remaining duration will on average equal one half of the total duration. Therefore the duration dummy variable categories correspond to the remaining duration, scaled up by a factor of two. Of course, there will be random measurement errors with respect to the true desired variable, which is the actual time remaining on the job. One's inferences about the impact of remaining duration on search activity will, then, be biased downward, since, for example, some people in the 6-12 month category will have less time remaining on their job than some people in the $<6$ month category.

The controls include age, age squared, dummy variables for low (ISCED levels 0-2) and middle levels (ISCED level 3) of schooling with high levels of schooling the omitted category (ISCED levels 5-7), a female dummy, the log of hourly earnings expressed in purchasing power parity units in 2001 US dollars, the regional unemployment rate, year dummy variables, and country dummy variables. ${ }^{10}$ The regional unemployment rate information was collected from the European Labour Force Survey and matched to the regional indicators in the ECHP data. ${ }^{11}$ The unemployment rate, human capital and gender controls account for likely wage offers relative to the current wage, which is also a control. Country dummy variables control for international differences in the job search environment, while year dummies account for

\footnotetext{
${ }^{10}$ The ECHP provides purchasing power parity rates for each country in each year, allowing one to transform the earnings data into US purchasing power units for that year. These transformed earnings variables were then corrected for US inflation by using the Personal Consumption Expenditures deflator for the US, taken from www.bea.gov. I excluded observations with hourly earnings less than $\$ 1$ or greater than $\$ 300$ in 2001 purchasing power parity units. These exclusions amounted to about $0.3 \%$ of the sample.

${ }^{11}$ I am grateful to Alison Davies and Rhys Powell for their help in acquiring the European Labour Force Survey regional unemployment rate data. Since the ECHP did not collect regional information for Denmark or the Netherlands, I used the national unemployment rate for those countries.
} 
continent-wide economic factors, as well as for the value of the US dollar in purchasing power. The standard errors were clustered at the country-year level.

In addition to the basic equation (24), which constrains the effects of job duration to be same across the sample, I also estimated several alternative specifications. First, I estimated the basic model separately by country and gender. This specification allows each country's laws and economic structure to have different effects on search intensity as well as for possible gender differences in search behavior. In particular, continued inclusion of time dummies in the models disaggregated by country allows each country to have a flexible trend in its job search intensity. In the models disaggregated by country, standard errors were clustered at the year level. Second, the models were also estimated using individual fixed effects, where I take advantage of the longitudinal nature of the ECHP data. These models account for possibly spurious correlation between an individual's propensity to search and the type of job one has. For example, if most workers want a permanent job, then other things being equal, those who are most willing to look hard for work will be most likely to have permanent jobs. If this willingness is a fixed trait, then we may observe a spurious negative correlation between search intensity and the incidence of temporary work. Fixed effect models can account for this possibility.

Table 5 contains basic regression results for the determinants of search intensity among employed workers. Looking first at the full sample results, we see that the increase in search intensity from permanent jobs to short duration temporary jobs is very similar to the raw means shown in Table 1. Active searching increases by a highly significant 4.72 percentage points going from permanent jobs to longest duration temporary jobs, all else equal. The incidence further increases to $7.09 \%$ for jobs with 6-12 months duration and all the way to $16.17 \%$ for the shortest duration jobs. Among temporary jobs, $79 \%$ of the increase in search intensity that occurs between the longest and the shortest duration jobs occurs in the last period. This latter increase is also highly significant. Other results for the full sample are that older workers have lower search intensity (the negative quadratic term outweighs the positive term for all ages greater than 11.1 years), more highly educated workers have higher search activity levels, and 
women, high wage workers and workers in areas with high unemployment rates all have lower levels of search intensity. The results for gender and education are intuitive since I have controlled for hourly pay: for women and the less educated, a given wage is higher up in the potential wage distribution than it is for men and the highly educated, lowering the former groups' returns to search (Blau and Kahn 1981). Table 5's results for men and women separately are very similar to those of the pooled sample, and together they confirm that the raw increase in search intensity observed in the overall means as duration falls is not simply a compositional effect.

Table 6 shows that these results for the pooled ECHP sample largely hold up within individual countries. First, for each country, search intensity is significantly greater for those in temporary jobs than on permanent jobs. While search intensity doesn't always monotonically increase as contract duration falls, it generally rises, and in every case, it is much higher for the shortest duration contract than for longest duration temporary jobs. ${ }^{12}$ The fraction of the total increase in search intensity among temporary job durations that occurs in the shortest jobs ranges from a low of .388 in Denmark to 0.932 in Portugal, with a median of about .72. Again, searchers are forward looking, and the shortest duration jobs have the most search intensity. Appendix Tables A2 and A3 show the estimates separately by country and by gender. Again, with some exceptions possibly due to small cell sizes, the general patterns shown in the pooled results of Table 6 hold up.

Up to now, I have treated differences in search behavior across individuals with different temporary contract durations as if we were observing the same individual under alternative potential job duration levels. For example, those in jobs with less than 6 months duration search harder than those in permanent jobs, controlling for wages, unemployment rates, gender, etc. It is possible, however, that these individuals differ in unmeasured ways and that these differences in search intensity don't represent the causal impact of a shorter job duration. To take account of this possibility, Tables 7, 8, A4 and A5 use the longitudinal feature of the ECHP to estimate

\footnotetext{
12 An exception to monotonicity is a seemingly anomalous rise to $15.7 \%$ for those in $12-24$ month contracts in Italy.
} 
fixed effects models of job search intensity. Here we ask whether an individual searches harder in a short job than he/she did in a longer duration job, a question closer in spirit to the theoretical model presented earlier. Table 7 shows results for all 8 countries pooled and separately by gender. Only time-varying explanatory variables are included, since all variables are defined as deviations from their within-person means. ${ }^{13}$ The basic results are very similar to those presented earlier. First, in the full sample, being in a long duration temporary job (the 24+ months category) leads one to raise search intensity by 2.0 percentage points relative to being in a permanent job, an effect that is marginally significant. Search intensity then monotonically increases through the shortest temporary job, where with a contract duration less than 6 months, one is 12.6 percentage points more likely to pursue active search measures than in permanent job. $85 \%$ of the rise in intensity within temporary jobs occurs in the shortest jobs. Wages continue to significantly negatively affect search intensity, as the search model predicts.

These results largely hold up when I disaggregate by gender, although for men the progression through shorter temporary contract durations is not monotonic. But the search intensity is still much greater for men in the shortest jobs than in all other categories and actually $100 \%$ of the rise in intensity within temporary jobs occurs in the shortest jobs. Women's results are qualitatively similar except that the $24+$ category has virtually identical search intensity to that in permanent jobs. For women, $69 \%$ of the rise in search intensity within temporary jobs occurs in the shortest jobs. A further interesting result concerns the relative effects of wages for men and women. In both cases, the effects are negative and statistically significant. But the magnitude is more than twice as high for men as for women. Since the sample mean search intensity is 0.061 for men and 0.064 for women, men's search elasticity with respect to wages is more than twice as high as women's. This suggests a higher labor supply elasticity to the firm for men than women, a factor that could help explain part of the gender pay gap. ${ }^{14}$

\footnotetext{
13 The schooling variables are included because some of the respondents increased their schooling between surveys. 14 The evidence on the relative wage elasticity of male and female quitting is somewhat mixed. See, for example, Blau and Kahn (1981), Viscusi (1980), Barth and Dale-Olsen (1999), and Ransom and Oaxaca (2009). Table 5 showed a slightly more negative coefficient on wages for women than men, although that result did not control for individual fixed effects.
} 
Table 8 shows individual fixed results separately by country. The findings are very similar to the earlier results by country not taking into account individual fixed effects (Table 6). Again, while the pattern is not always monotonic as we shorten the contract duration, in each country, workers search considerably harder on average in the shortest jobs. Finally, Tables A4 and A5 show individual fixed effects by country disaggregated by gender. The main results still hold up, although there are now some exceptions to the basic finding of the highest search intensity in the shortest jobs (eg men in Belgium or Denmark and women in Portugal).

\section{Conclusions}

In this paper, I have examined the job search behavior of those employed in temporary jobs with a known duration level. A theoretical model of optimal search from a temporary job was constructed, and it predicts that workers employed in shorter duration temporary jobs would search harder than those in longer duration temporary jobs. Moreover, calibration of the model to the ECHP data implied that at least $59 \%$ of the increase in search intensity over the life a long term temporary job would occur in the last period. I then used the ECHP data on employed workers for 1995-2001 from 8 countries to study the impact of contract duration on job search intensity. The countries were Belgium, Denmark, Finland, France, Italy, the Netherlands, Portugal and Spain. In regression models that controlled for human capital, pay, local unemployment, gender, and time and country fixed effects, I found that workers on temporary jobs indeed search harder than those on permanent jobs. Moreover, search intensity increases as temporary job duration falls, and at least $80 \%$ of this increase occurs on average in the shortest duration jobs. These results largely held up when I disaggregated by gender and country as well as when I estimated individual fixed effects models that used the longitudinal feature of the ECHP data. These empirical results are noteworthy, since it was not necessary to assume myopia or hyperbolic discounting in order to explain them, although the data clearly also do not rule out such explanations. 
From a policy perspective, if a goal of labor policy is to move people into permanent jobs, then one needs to consider workers' search incentives. Recent policy changes have in many cases encouraged firms to create temporary jobs or to increase the number of temporary contracts a firm may offer a worker. The results obtained here suggest that these policies will lead to a reduction in workers' average search intensity if they lead to longer duration temporary contracts. One must weigh the direct benefits to a worker of having a longer duration contract with the reduction in search effort to find a more permanent job. This is a similar dilemma to that for designing unemployment benefit systems that try to balance the gains to better income support for workers with reduced incentives to find work. 


\section{References}

Autor, David H. and Susan N. Houseman, "Do Temporary Help Jobs Improve Labor Market Outcomes for Low-Skilled Workers? Evidence from Random Assignments," working paper, MIT, October 2005.

Barth, Erling and Harald Dale-Olsen, "Monopsonistic Discrimination and the Gender Wage Gap." Cambridge, MA: National Bureau of Economic Research, Working Paper 7197, 1999.

Blau, Francine D., and Lawrence M. Kahn, "Race and Sex Differences in Quits by Young Workers," Industrial \& Labor Relations Review, 34, No. 4 (July 1981): 563-577.

Blanchard, Olivier and Augustin Landier, "The Perverse Effects of Partial Labour Market Reform: Fixed-Term Contracts in France," Economic Journal 112, no. 480 (June 2002): F214-F244.

Booth, Alison L., Marco Francesconi and Jeff Frank, "Temporary Jobs: Stepping Stones or Dead Ends,” Economic Journal 112, no. 480 (June 2002): F189-F213.

Burdett, Kenneth, "Unemployment Insurance Payments as a Search Subsidy: A Theoretical Analysis," Economic Inquiry 27, no. 3 (July 1979): 333-343.

Cahuc, Pierre, and Fabien Postel-Vinay, "Temporary Jobs, Employment Protection and Labor Market Performance," Labour Economics 9, no. 1 (February 2002): 63-91.

Della Vigna, Stefano and M. Daniele Paserman, "Job Search and Impatience," Journal of Labor Economics 23, no. 3 (July 2005): 527-588.

Kahn, Lawrence M., "Employment Protection Reforms, Employment and the Incidence of Temporary Jobs in Europe: 1995-2001." Bonn, Germany: IZA, Discussion Paper 3241, December 2007a.

Kahn, Lawrence M., "The Impact of Employment Protection Mandates on Demographic Temporary Employment Patterns: International Microeconomic Evidence," Economic Journal 117, no. 521 (June 2007b): F333-F356.

Katz, Lawrence F. and Bruce D. Meyer, "The Impact of the Potential Duration of Unemployment Benefits on the Duration of Unemployment," Journal of Public Economics 41, no. 1 (February 1990): 45-72.

Mortensen, Dale T., "A Structural Model of Unemployment Insurance Benefit Effects on the Incidence and Duration of Unemployment," in Yoram Weiss and Gideon Fishelson, eds., Advances in the Theory and Measurement of Unemployment (New York: St. Martin's Press, 1990), pp. 57-81.

Nickell, Stephen, and Richard Layard. "Labor Market Institutions and Economic Performance," in Orley Ashenfelter and David Card, eds., Handbook of Labor Economics, Volume 3C (Amsterdam: North-Holland, 1999), pp. 3029-3084.

OECD, Employment Outlook: 2004 (Paris: OECD, 2004). 
Paserman, M. Daniele, "Job Search and Hyperbolic Discounting: Structural Estimation and Policy Evaluation,” The Economic Journal 118, no. 531 (August 2008): 1418-1452.

Ransom, Michael R. and Ronald L. Oaxaca, "New Market Power Models and Sex Differences in Pay," Princeton: Industrial Relations Section Working Paper No. 540, January 2009.

Viscusi, W. Kip, "Sex Differences in Worker Quitting," The Review of Economics and Statistics 62, no. 3 (August 1980): 388-398. 
Table 1: Contract Duration and On the Job Search Effort, 1995-2001 (employed workers)

Employment Contract Type Fraction of Sample Incidence of On the Job Search Incidence of Active Search Behavior Sample Size

A. Temporary Contract

\begin{tabular}{lllll}
\hline$<6$ months & 0.026 & 0.291 & 0.230 & 5142 \\
6 months to $<1$ year & 0.044 & 0.179 & 0.132 & 8669 \\
1 year to under 2 years & 0.021 & 0.179 & 0.131 & 4048 \\
2 years to under 5 years & 0.010 & 0.151 & 0.113 & 1883 \\
5 years or more & 0.003 & 0.182 & 0.118 & 553 \\
2 years or more & 0.013 & 0.158 & 0.114 & 2436 \\
B. Permanent Contract & 0.900 & 0.082 & 0.052 & 170410 \\
Total & & & 0.062 & 190705 \\
\hline
\end{tabular}

Source: ECHP data. Adjusted sampling weights used, where the raw weights are modified so that each country receives the same total weight. Sample is limited to those age 16-65 from the following countries: Belgium, Denmark, Finland, France, Italy, the Netherlands, Portugal, and Spain. 
Table 2: Contract Duration Incidence by Country, 1995-2001

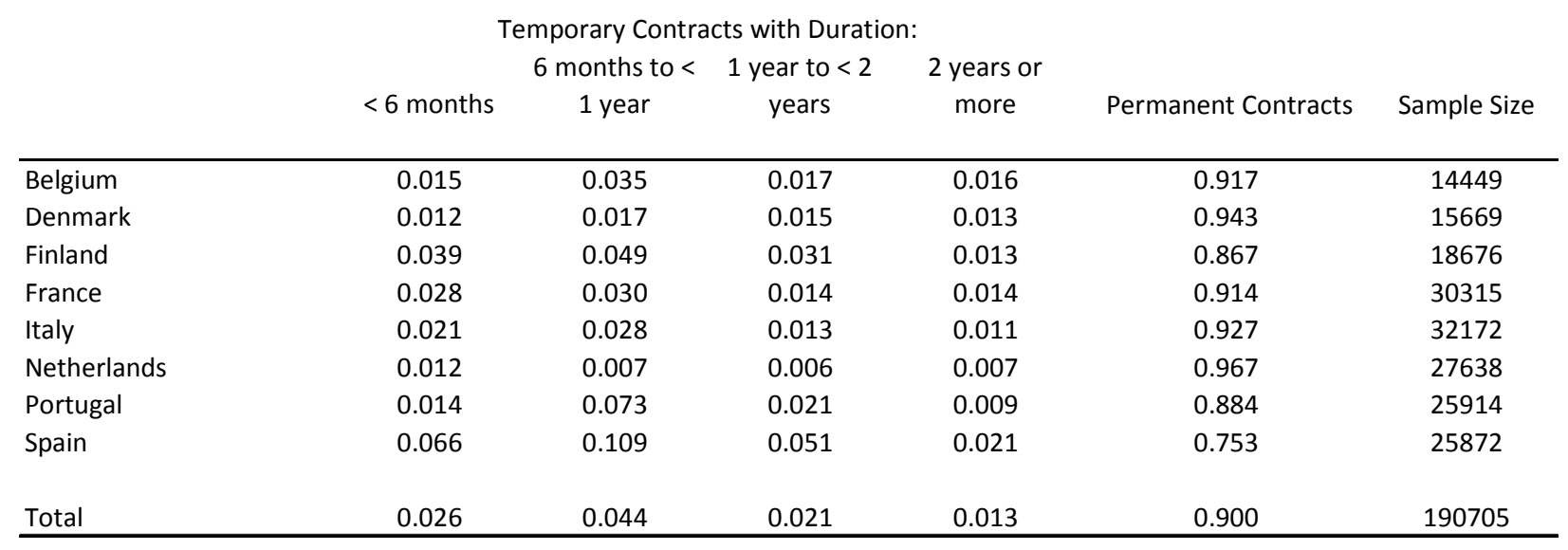


Table 3: Incidence of On the Job Search by Contract Duration

Temporary Contracts with Duration:

6 months to $<1$ year to $<2 \quad 2$ years or

$<6$ months 1 year years more Permanent contracts

\begin{tabular}{lccccc}
\hline Belgium & 0.270 & 0.184 & 0.212 & 0.137 & 0.063 \\
cell size & 227 & 498 & 242 & 205 & 13277 \\
Denmark & 0.344 & 0.294 & 0.260 & 0.197 & 0.091 \\
cell size & 176 & 282 & 262 & 192 & 14757 \\
Finland & 0.254 & 0.203 & 0.179 & 0.168 & 0.092 \\
cell size & 757 & 926 & 595 & 257 & 16141 \\
France & 0.417 & 0.275 & 0.212 & 0.109 & 0.050 \\
cell size & 880 & 964 & 437 & 440 & 27594 \\
Italy & 0.333 & 0.228 & 0.272 & 0.214 & 0.061 \\
cell size & 746 & 1006 & 441 & 403 & 29576 \\
Netherlands & 0.394 & 0.386 & 0.429 & 0.314 & 0.206 \\
cell size & 310 & 179 & 160 & 191 & 26798 \\
Portugal & 0.160 & 0.076 & 0.070 & 0.077 & 0.024 \\
cell size & 300 & 1950 & 604 & 183 & 22877 \\
Spain & 0.250 & 0.163 & 0.127 & 0.131 & 0.059 \\
cell size & 1746 & 2864 & 1307 & 565 & 19390 \\
& & & & & \\
Total & 0.291 & 0.179 & 0.179 & 0.158 & 0.082 \\
cell size & 5142 & 8669 & 4048 & 2436 & 170410 \\
\hline
\end{tabular}


Table 4: Incidence of Active On the Job Search Measures by Contract Duration

Temporary Contracts with Duration:

6 months to $<1$ year to $<2 \quad 2$ years or

$<6$ months 1 year years more Permanent contracts

\begin{tabular}{lccccc}
\hline Belgium & 0.178 & 0.126 & 0.132 & 0.092 & 0.037 \\
cell size & 227 & 498 & 242 & 205 & 13277 \\
Denmark & 0.284 & 0.229 & 0.206 & 0.157 & 0.073 \\
cell size & 176 & 282 & 262 & 192 & 14757 \\
Finland & 0.217 & 0.163 & 0.137 & 0.150 & 0.068 \\
cell size & 757 & 926 & 595 & 257 & 16141 \\
France & 0.296 & 0.169 & 0.129 & 0.071 & 0.033 \\
cell size & 880 & 964 & 437 & 440 & 27594 \\
Italy & 0.265 & 0.154 & 0.229 & 0.142 & 0.044 \\
cell size & 746 & 1006 & 441 & 403 & 29576 \\
Netherlands & 0.303 & 0.248 & 0.245 & 0.193 & 0.097 \\
cell size & 310 & 179 & 160 & 191 & 26798 \\
Portugal & 0.122 & 0.051 & 0.052 & 0.044 & 0.013 \\
cell size & 300 & 1950 & 604 & 183 & 22877 \\
Spain & 0.210 & 0.134 & 0.101 & 0.099 & 0.046 \\
cell size & 1746 & 2864 & 1307 & 565 & 19390 \\
& & & & & \\
Total & 0.230 & 0.132 & 0.131 & 0.114 & 0.052 \\
cell size & 5142 & 8669 & 4048 & 2436 & 170410 \\
\hline
\end{tabular}


Table 5: Regression Results for Search Intensity (incidence of active job search measures), Pooled Across Countries

\begin{tabular}{|c|c|c|c|c|c|c|}
\hline \multirow[t]{2}{*}{ Explanatory Variables } & \multicolumn{2}{|c|}{ Full Sample } & \multicolumn{2}{|c|}{ Men } & \multicolumn{2}{|c|}{ Women } \\
\hline & coef & se & coef & se & coef & se \\
\hline age & 0.0009 & 0.0006 & 0.0025 & 0.0008 & -0.0011 & 0.0008 \\
\hline age squared & -0.00004 & 0.00001 & -0.00006 & 0.00001 & -0.00001 & 0.00001 \\
\hline low level schooling & -0.0338 & 0.0038 & -0.0355 & 0.0041 & -0.0331 & 0.0047 \\
\hline middle level schooling & -0.0251 & 0.0029 & -0.0298 & 0.0032 & -0.0200 & 0.0036 \\
\hline female & -0.0063 & 0.0016 & & & & \\
\hline contract duration $<6$ mos & 0.1617 & 0.0098 & 0.1657 & 0.0144 & 0.1565 & 0.0113 \\
\hline contract duration 6-12 mos & 0.0709 & 0.0069 & 0.0730 & 0.0092 & 0.0687 & 0.0080 \\
\hline contract duration $12-24 \mathrm{mos}$ & 0.0648 & 0.0093 & 0.0631 & 0.0123 & 0.0664 & 0.0110 \\
\hline contract duration $24+$ mos & 0.0472 & 0.0087 & 0.0584 & 0.0126 & 0.0351 & 0.0101 \\
\hline regional unemployment rate & -0.0004 & 0.0002 & -0.0001 & 0.0002 & -0.0009 & 0.0003 \\
\hline log real hourly earnings & -0.0267 & 0.0035 & -0.0249 & 0.0041 & -0.0298 & 0.0041 \\
\hline year dummies? & \multicolumn{2}{|c|}{ yes } & \multicolumn{2}{|c|}{ yes } & \multicolumn{2}{|c|}{ yes } \\
\hline country dummies? & \multicolumn{2}{|c|}{ yes } & \multicolumn{2}{|c|}{ yes } & \multicolumn{2}{|c|}{ yes } \\
\hline sample size & \multicolumn{2}{|c|}{190705} & \multicolumn{2}{|c|}{108958} & \multicolumn{2}{|c|}{81747} \\
\hline
\end{tabular}

Standard errors clustered at the country-year level. 
Table 6: Selected Regression Results for Search Intensity (incidence of active job search measures), Separately by Country, Pooled by Gender

\begin{tabular}{|c|c|c|c|c|c|c|c|c|}
\hline \multirow[t]{2}{*}{ Explanatory Variables } & \multicolumn{2}{|c|}{ Belgium } & \multicolumn{2}{|c|}{ Denmark } & \multicolumn{2}{|c|}{ Finland } & \multicolumn{2}{|c|}{ France } \\
\hline & coef & se & coef & se & coef & se & coef & se \\
\hline$\overline{\text { age }}$ & -0.006 & 0.002 & 0.001 & 0.002 & 0.002 & 0.002 & -0.003 & 0.002 \\
\hline age squared & 0.00005 & 0.00002 & -0.00005 & 0.00003 & -0.00005 & 0.00002 & 0.00001 & 0.00002 \\
\hline low level schooling & -0.032 & 0.005 & -0.019 & 0.010 & -0.042 & 0.003 & -0.019 & 0.003 \\
\hline middle level schooling & -0.029 & 0.005 & -0.008 & 0.010 & -0.028 & 0.004 & -0.020 & 0.003 \\
\hline female & -0.013 & 0.005 & -0.006 & 0.006 & -0.002 & 0.005 & -0.009 & 0.003 \\
\hline contract duration $<6$ mos & 0.117 & 0.035 & 0.188 & 0.044 & 0.129 & 0.019 & 0.235 & 0.026 \\
\hline contract duration $6-12$ mos & 0.060 & 0.019 & 0.138 & 0.025 & 0.072 & 0.026 & 0.114 & 0.016 \\
\hline contract duration $12-24$ mos & 0.065 & 0.031 & 0.114 & 0.029 & 0.044 & 0.014 & 0.071 & 0.025 \\
\hline contract duration $24+$ mos & 0.038 & 0.038 & 0.059 & 0.032 & 0.059 & 0.019 & 0.017 & 0.018 \\
\hline regional unemployment rate & -0.0003 & 0.0003 & 0.0058 & 0.0003 & -0.0026 & 0.0011 & -0.0007 & 0.0003 \\
\hline log real hourly earnings & -0.038 & 0.005 & -0.018 & 0.011 & -0.033 & 0.009 & -0.019 & 0.005 \\
\hline year dummies? & $y$ & & ye & & ye & & $\mathrm{y}$ & \\
\hline sample size & 14 & & 156 & & 186 & & 30 & \\
\hline \multirow[t]{2}{*}{ Explanatory Variables } & \multicolumn{2}{|c|}{ Italy } & \multicolumn{2}{|c|}{ Netherlands } & \multicolumn{2}{|c|}{ Portugal } & \multicolumn{2}{|c|}{ Spain } \\
\hline & coef & se & coef & se & coef & se & coef & se \\
\hline age & -0.003 & 0.001 & 0.006 & 0.002 & 0.000 & 0.001 & 0.004 & 0.001 \\
\hline age squared & 0.00002 & 0.00001 & -0.00011 & 0.00002 & -0.00001 & 0.00001 & -0.00006 & 0.00001 \\
\hline low level schooling & -0.033 & 0.008 & -0.037 & 0.008 & -0.027 & 0.007 & -0.072 & 0.011 \\
\hline middle level schooling & -0.021 & 0.007 & -0.033 & 0.006 & -0.018 & 0.004 & -0.037 & 0.008 \\
\hline female & -0.007 & 0.004 & -0.001 & 0.003 & -0.004 & 0.003 & -0.008 & 0.007 \\
\hline contract duration $<6$ mos & 0.201 & 0.018 & 0.187 & 0.036 & 0.101 & 0.033 & 0.147 & 0.014 \\
\hline contract duration 6-12 mos & 0.095 & 0.016 & 0.134 & 0.048 & 0.032 & 0.006 & 0.068 & 0.010 \\
\hline contract duration $12-24$ mos & 0.157 & 0.024 & 0.134 & 0.032 & 0.033 & 0.016 & 0.038 & 0.013 \\
\hline contract duration $24+$ mos & 0.068 & 0.016 & 0.095 & 0.033 & 0.027 & 0.031 & 0.037 & 0.011 \\
\hline regional unemployment rate & 0.00002 & 0.0002 & -0.0050 & 0.0004 & 0.0037 & 0.0007 & -0.0009 & 0.0005 \\
\hline log real hourly earnings & -0.057 & 0.008 & -0.004 & 0.005 & -0.013 & 0.002 & -0.060 & 0.011 \\
\hline year dummies? & \multicolumn{2}{|c|}{ yes } & \multicolumn{2}{|c|}{ yes } & \multicolumn{2}{|c|}{ yes } & \multicolumn{2}{|c|}{ yes } \\
\hline sample size & \multicolumn{2}{|c|}{32172} & \multicolumn{2}{|c|}{27638} & \multicolumn{2}{|c|}{25914} & \multicolumn{2}{|c|}{25872} \\
\hline
\end{tabular}


Table 7: Individual Fixed Effects Regression Results for Search Intensity (incidence of active job search measures), Pooled Across Countries

\begin{tabular}{|c|c|c|c|c|c|c|}
\hline \multirow[t]{2}{*}{ Explanatory Variables } & \multicolumn{2}{|c|}{ Full Sample } & \multicolumn{2}{|c|}{ Men } & \multicolumn{2}{|c|}{ Women } \\
\hline & coef & se & coef & se & coef & se \\
\hline$\overline{\text { age }}$ & -0.005 & 0.002 & -0.002 & 0.003 & -0.008 & 0.003 \\
\hline age squared & 0.00004 & 0.00002 & 0.00001 & 0.00002 & 0.00008 & 0.00003 \\
\hline low level schooling & 0.000 & 0.008 & 0.011 & 0.013 & -0.014 & 0.012 \\
\hline middle level schooling & 0.012 & 0.009 & 0.017 & 0.014 & 0.005 & 0.009 \\
\hline contract duration $<6$ mos & 0.126 & 0.009 & 0.135 & 0.011 & 0.115 & 0.015 \\
\hline contract duration $6-12$ mos & 0.036 & 0.008 & 0.039 & 0.012 & 0.034 & 0.010 \\
\hline contract duration $12-24 \mathrm{mos}$ & 0.025 & 0.009 & 0.015 & 0.014 & 0.033 & 0.011 \\
\hline contract duration $24+$ mos & 0.020 & 0.009 & 0.039 & 0.015 & -0.002 & 0.015 \\
\hline regional unemployment rate & 0.0001 & 0.0004 & -0.0003 & 0.0006 & 0.0005 & 0.0007 \\
\hline log real hourly earnings & -0.022 & 0.006 & -0.029 & 0.007 & -0.012 & 0.007 \\
\hline year dummies? & \multicolumn{2}{|c|}{ yes } & \multicolumn{2}{|c|}{ yes } & \multicolumn{2}{|c|}{ yes } \\
\hline country dummies? & \multicolumn{2}{|c|}{ no } & \multicolumn{2}{|c|}{ no } & \multicolumn{2}{|c|}{ no } \\
\hline sample size & \multicolumn{2}{|c|}{190705} & \multicolumn{2}{|c|}{108958} & \multicolumn{2}{|c|}{81747} \\
\hline
\end{tabular}

Standard errors clustered at the country-year level. 
Table 8: Selected individual Fixed Effects Regression Results for Search Intensity (incidence of active job search measures),

\begin{tabular}{|c|c|c|c|c|c|c|c|c|}
\hline \multirow{3}{*}{ Explanatory Variables } & \multicolumn{6}{|c|}{ Separately by Country, Pooled by Gender } & \multirow{2}{*}{\multicolumn{2}{|c|}{ France }} \\
\hline & \multicolumn{2}{|c|}{ Belgium } & \multicolumn{2}{|c|}{ Denmark } & \multicolumn{2}{|c|}{ Finland } & & \\
\hline & coef & se & coef & se & coef & se & coef & se \\
\hline age & -0.007 & 0.007 & 0.00005 & 0.006 & -0.015 & 0.004 & -0.004 & 0.002 \\
\hline age squared & 0.00010 & 0.00009 & -0.00006 & 0.00007 & 0.00012 & 0.00004 & 0.00001 & 0.00002 \\
\hline low level schooling & -0.033 & 0.028 & -0.025 & 0.021 & 0.026 & 0.010 & -0.056 & 0.061 \\
\hline middle level schooling & -0.036 & 0.023 & 0.005 & 0.023 & 0.048 & 0.010 & -0.045 & 0.024 \\
\hline contract duration $<6$ mos & 0.074 & 0.040 & 0.165 & 0.038 & 0.125 & 0.025 & 0.173 & 0.022 \\
\hline contract duration 6-12 mos & 0.002 & 0.032 & 0.117 & 0.022 & 0.049 & 0.029 & 0.060 & 0.015 \\
\hline contract duration $12-24$ mos & -0.004 & 0.031 & 0.085 & 0.031 & 0.003 & 0.013 & 0.042 & 0.018 \\
\hline contract duration $24+$ mos & 0.034 & 0.036 & 0.012 & 0.041 & 0.008 & 0.026 & -0.011 & 0.015 \\
\hline regional unemployment rate & 0.0005 & 0.0002 & & & -0.0008 & 0.0011 & -0.0016 & 0.0030 \\
\hline log real hourly earnings & -0.026 & 0.012 & -0.023 & 0.019 & -0.029 & 0.020 & 0.007 & 0.009 \\
\hline year dummies? & ye & & ye & & y€ & & $y \epsilon$ & \\
\hline sample size & 144 & & 156 & & 186 & & 303 & \\
\hline \multirow[t]{2}{*}{ Explanatory Variables } & \multicolumn{2}{|c|}{ Italy } & \multicolumn{2}{|c|}{ Netherlands } & \multicolumn{2}{|c|}{ Portugal } & \multicolumn{2}{|c|}{ Spain } \\
\hline & coef & se & coef & se & coef & se & coef & se \\
\hline age & -0.011 & 0.003 & -0.008 & 0.005 & 0.001 & 0.002 & -0.010 & 0.006 \\
\hline age squared & 0.00010 & 0.00003 & 0.00011 & 0.00006 & 0.00000 & 0.00001 & 0.00003 & 0.00006 \\
\hline low level schooling & -0.009 & 0.050 & 0.010 & 0.029 & 0.006 & 0.019 & -0.033 & 0.019 \\
\hline middle level schooling & -0.011 & 0.047 & 0.044 & 0.032 & 0.008 & 0.016 & -0.007 & 0.022 \\
\hline contract duration $<6$ mos & 0.134 & 0.012 & 0.179 & 0.021 & 0.080 & 0.026 & 0.097 & 0.018 \\
\hline contract duration 6-12 mos & 0.032 & 0.016 & 0.055 & 0.031 & 0.012 & 0.005 & 0.023 & 0.019 \\
\hline contract duration $12-24$ mos & 0.058 & 0.036 & 0.017 & 0.031 & 0.029 & 0.010 & 0.008 & 0.017 \\
\hline contract duration $24+$ mos & 0.043 & 0.024 & 0.069 & 0.036 & 0.005 & 0.022 & 0.006 & 0.014 \\
\hline regional unemployment rate & 0.0036 & 0.0021 & & & 0.0043 & 0.0017 & -0.0026 & 0.0012 \\
\hline log real hourly earnings & -0.048 & 0.009 & -0.014 & 0.011 & -0.024 & 0.008 & -0.055 & 0.026 \\
\hline year dummies? & ye & & ye & & ye & & ye & \\
\hline sample size & 321 & & 276 & & $25 c$ & & 258 & \\
\hline
\end{tabular}

Standard errors clustered at the year level. 
Table A1: Transition Rates for Jobseekers: From Temporary Jobs to Permanent or New Temporary Jobs

\begin{tabular}{|c|c|c|c|}
\hline \multirow[t]{2}{*}{ Temporary Job Duration } & \multicolumn{2}{|c|}{ Transitions to: } & \multirow[b]{2}{*}{$\mathrm{N}$} \\
\hline & Permanent Job & New Temporary Job & \\
\hline$<6$ months & 0.422 & 0.136 & 795 \\
\hline $6-12$ months & 0.499 & 0.107 & 781 \\
\hline $12-24$ months & 0.478 & 0.057 & 358 \\
\hline $24+$ months & 0.600 & 0.066 & 168 \\
\hline All & 0.479 & 0.103 & 2102 \\
\hline
\end{tabular}

Sample includes people in temporary jobs who were searching for a new job. 
Table A2: Selected Regression Results for Search Intensity (incidence of active job search measures), Separately by Country, Men

\begin{tabular}{|c|c|c|c|c|c|c|c|c|}
\hline \multirow[t]{2}{*}{ Explanatory Variables } & \multicolumn{2}{|c|}{ Belgium } & \multicolumn{2}{|c|}{ Denmark } & \multicolumn{2}{|c|}{ Finland } & \multicolumn{2}{|c|}{ France } \\
\hline & coef & se & coef & se & coef & se & coef & se \\
\hline age & -0.006 & 0.002 & 0.001 & 0.003 & 0.002 & 0.003 & -0.002 & 0.004 \\
\hline age squared & 0.00005 & 0.00002 & -0.00005 & 0.00004 & -0.00006 & 0.00003 & 0.00000 & 0.00005 \\
\hline low level schooling & -0.041 & 0.008 & -0.017 & 0.011 & -0.043 & 0.006 & -0.027 & 0.004 \\
\hline middle level schooling & -0.037 & 0.010 & -0.014 & 0.008 & -0.039 & 0.005 & -0.027 & 0.005 \\
\hline contract duration $<6$ mos & 0.093 & 0.044 & 0.145 & 0.048 & 0.098 & 0.049 & 0.267 & 0.026 \\
\hline contract duration 6-12 mos & 0.049 & 0.026 & 0.284 & 0.058 & 0.085 & 0.034 & 0.104 & 0.021 \\
\hline contract duration $12-24$ mos & 0.081 & 0.059 & 0.164 & 0.038 & 0.034 & 0.020 & 0.017 & 0.024 \\
\hline contract duration $24+$ mos & 0.062 & 0.060 & 0.105 & 0.042 & 0.076 & 0.036 & 0.016 & 0.033 \\
\hline regional unemployment rate & -0.0005 & 0.0003 & 0.0094 & 0.0003 & -0.0033 & 0.0013 & -0.0011 & 0.0003 \\
\hline log real hourly earnings & -0.048 & 0.007 & -0.020 & 0.010 & -0.039 & 0.018 & -0.021 & 0.003 \\
\hline year dummies? & y & & ye & & ye & & ye & \\
\hline sample size & 78 & & 80 & & 92 & & 163 & \\
\hline \multirow[t]{2}{*}{ Explanatory Variables } & & \multicolumn{2}{|c|}{ Netherlands } & \multicolumn{2}{|c|}{ Portugal } & \multicolumn{2}{|c|}{ Spain } \\
\hline & coef & se & coef & se & coef & se & coef & se \\
\hline age & 0.002 & 0.001 & 0.010 & 0.002 & 0.002 & 0.001 & 0.005 & 0.002 \\
\hline age squared & -0.00004 & 0.00001 & -0.00017 & 0.00002 & -0.00002 & 0.00001 & -0.00007 & 0.00002 \\
\hline low level schooling & -0.032 & 0.011 & -0.030 & 0.011 & -0.028 & 0.006 & -0.068 & 0.009 \\
\hline middle level schooling & -0.021 & 0.007 & -0.034 & 0.007 & -0.020 & 0.005 & -0.033 & 0.007 \\
\hline contract duration $<6$ mos & 0.216 & 0.030 & 0.261 & 0.060 & 0.087 & 0.021 & 0.152 & 0.016 \\
\hline contract duration 6-12 mos & 0.109 & 0.025 & 0.091 & 0.027 & 0.031 & 0.010 & 0.060 & 0.015 \\
\hline contract duration $12-24$ mos & 0.162 & 0.031 & 0.220 & 0.061 & 0.026 & 0.013 & 0.026 & 0.007 \\
\hline contract duration $24+$ mos & 0.033 & 0.012 & 0.163 & 0.066 & 0.045 & 0.041 & 0.035 & 0.015 \\
\hline regional unemployment rate & 0.0004 & 0.0002 & -0.0039 & 0.0005 & 0.0028 & 0.0009 & -0.0002 & 0.0007 \\
\hline log real hourly earnings & -0.051 & 0.012 & 0.004 & 0.008 & -0.005 & 0.004 & -0.054 & 0.009 \\
\hline year dummies? & \multicolumn{2}{|c|}{ yes } & \multicolumn{2}{|c|}{ yes } & \multicolumn{2}{|c|}{ yes } & \multicolumn{2}{|c|}{ yes } \\
\hline sample size & \multicolumn{2}{|c|}{19539} & \multicolumn{2}{|c|}{16455} & \multicolumn{2}{|c|}{14822} & \multicolumn{2}{|c|}{16578} \\
\hline
\end{tabular}

Standard errors clustered at the year level. 
Table A3: Selected Regression Results for Search Intensity (incidence of active job search measures), Separately by Country, Women

\begin{tabular}{|c|c|c|c|c|c|c|c|c|}
\hline \multirow[t]{2}{*}{ Explanatory Variables } & \multicolumn{2}{|c|}{ Belgium } & \multicolumn{2}{|c|}{ Denmark } & \multicolumn{2}{|c|}{ Finland } & \multicolumn{2}{|c|}{ France } \\
\hline & coef & se & coef & se & coef & se & coef & se \\
\hline age & -0.006 & 0.004 & 0.002 & 0.001 & 0.001 & 0.003 & -0.005 & 0.001 \\
\hline age squared & 0.00005 & 0.00005 & -0.00006 & 0.00002 & -0.00005 & 0.00003 & 0.00004 & 0.00001 \\
\hline low level schooling & -0.017 & 0.007 & -0.024 & 0.012 & -0.041 & 0.007 & -0.011 & 0.008 \\
\hline middle level schooling & -0.018 & 0.006 & -0.001 & 0.013 & -0.017 & 0.009 & -0.013 & 0.004 \\
\hline contract duration $<6$ mos & 0.138 & 0.052 & 0.231 & 0.067 & 0.158 & 0.020 & 0.195 & 0.032 \\
\hline contract duration 6-12 mos & 0.068 & 0.024 & 0.057 & 0.030 & 0.064 & 0.028 & 0.122 & 0.012 \\
\hline contract duration $12-24 \mathrm{mos}$ & 0.048 & 0.022 & 0.088 & 0.026 & 0.049 & 0.022 & 0.114 & 0.033 \\
\hline contract duration $24+$ mos & 0.009 & 0.020 & -0.005 & 0.045 & 0.052 & 0.016 & 0.017 & 0.025 \\
\hline regional unemployment rate & 0.0000 & 0.0005 & 0.0022 & 0.0007 & -0.0020 & 0.0013 & -0.0002 & 0.0009 \\
\hline log real hourly earnings & -0.019 & 0.006 & -0.010 & 0.018 & -0.029 & 0.021 & -0.017 & 0.009 \\
\hline year dummies? & ye & & & & & & ye & \\
\hline sample size & 65 & & & & 94 & & 139 & \\
\hline \multirow[t]{2}{*}{ Explanatory Variables } & \multicolumn{2}{|c|}{ Italy } & \multicolumn{2}{|c|}{ Netherlands } & \multicolumn{2}{|c|}{ Portugal } & \multicolumn{2}{|c|}{ Spain } \\
\hline & coef & se & coef & se & coef & se & coef & se \\
\hline age & -0.011 & 0.001 & 0.000 & 0.002 & -0.002 & 0.001 & 0.005 & 0.002 \\
\hline age squared & 0.00011 & 0.00002 & -0.00004 & 0.00003 & 0.00002 & 0.00001 & -0.00007 & 0.00002 \\
\hline low level schooling & -0.039 & 0.009 & -0.044 & 0.007 & -0.034 & 0.013 & -0.081 & 0.017 \\
\hline middle level schooling & -0.023 & 0.010 & -0.031 & 0.007 & -0.021 & 0.009 & -0.044 & 0.012 \\
\hline contract duration $<6$ mos & 0.183 & 0.028 & 0.121 & 0.029 & 0.108 & 0.057 & 0.135 & 0.018 \\
\hline contract duration 6-12 mos & 0.080 & 0.032 & 0.173 & 0.087 & 0.031 & 0.009 & 0.079 & 0.016 \\
\hline contract duration $12-24$ mos & 0.152 & 0.032 & 0.072 & 0.053 & 0.038 & 0.029 & 0.056 & 0.031 \\
\hline contract duration $24+$ mos & 0.124 & 0.038 & 0.053 & 0.030 & 0.016 & 0.028 & 0.041 & 0.023 \\
\hline regional unemployment rate & -0.0005 & 0.0002 & -0.0069 & 0.0004 & 0.0051 & 0.0011 & -0.0026 & 0.0007 \\
\hline log real hourly earnings & -0.067 & 0.004 & -0.019 & 0.008 & -0.025 & 0.006 & -0.071 & 0.016 \\
\hline year dummies? & \multicolumn{2}{|c|}{ yes } & \multicolumn{2}{|c|}{ yes } & \multicolumn{2}{|c|}{ yes } & \multicolumn{2}{|c|}{ yes } \\
\hline sample size & \multicolumn{2}{|c|}{12633} & \multicolumn{2}{|c|}{11183} & \multicolumn{2}{|c|}{11092} & \multicolumn{2}{|c|}{9294} \\
\hline
\end{tabular}

Standard errors clustered at the year level. 
Table A4: Selected individual Fixed Effects Regression Results for Search Intensity (incidence of active job search measures), Separately by Country, Men

\begin{tabular}{|c|c|c|c|c|c|c|c|c|}
\hline \multirow[t]{2}{*}{ Explanatory Variables } & \multicolumn{2}{|c|}{ Belgium } & \multicolumn{2}{|c|}{ Denmark } & \multicolumn{2}{|c|}{ Finland } & \multicolumn{2}{|c|}{ France } \\
\hline & coef & se & coef & se & coef & se & coef & se \\
\hline$\overline{\text { age }}$ & -0.004 & 0.007 & 0.003 & 0.013 & -0.005 & 0.010 & 0.000 & 0.004 \\
\hline age squared & 0.00007 & 0.00009 & -0.00011 & 0.00016 & 0.000003 & 0.00010 & -0.00001 & 0.00004 \\
\hline low level schooling & -0.022 & 0.028 & -0.048 & 0.039 & 0.016 & 0.022 & 0.008 & 0.041 \\
\hline middle level schooling & -0.040 & 0.023 & -0.019 & 0.032 & 0.065 & 0.015 & -0.014 & 0.030 \\
\hline contract duration $<6$ mos & 0.062 & 0.025 & 0.128 & 0.058 & 0.090 & 0.037 & 0.211 & 0.033 \\
\hline contract duration 6-12 mos & 0.010 & 0.049 & 0.337 & 0.083 & 0.061 & 0.035 & 0.044 & 0.016 \\
\hline contract duration $12-24$ mos & -0.058 & 0.041 & 0.209 & 0.029 & 0.001 & 0.025 & 0.003 & 0.030 \\
\hline contract duration $24+$ mos & 0.095 & 0.056 & 0.050 & 0.026 & 0.016 & 0.048 & 0.010 & 0.033 \\
\hline regional unemployment rate & 0.000 & 0.001 & & & -0.001 & 0.002 & -0.002 & 0.003 \\
\hline log real hourly earnings & -0.031 & 0.021 & -0.050 & 0.019 & -0.041 & 0.016 & -0.008 & 0.012 \\
\hline year dummies? & ye & & ye & & & & & \\
\hline sample size & 78 & & 80 & & 92 & & 163 & \\
\hline \multirow[t]{2}{*}{ Explanatory Variables } & \multicolumn{2}{|c|}{ Italy } & \multicolumn{2}{|c|}{ Netherlands } & \multicolumn{2}{|c|}{ Portugal } & \multicolumn{2}{|c|}{ Spain } \\
\hline & coef & se & coef & se & coef & se & coef & se \\
\hline age & -0.008 & 0.003 & -0.007 & 0.006 & 0.001 & 0.003 & -0.002 & 0.007 \\
\hline age squared & 0.00007 & 0.00003 & 0.00008 & 0.00006 & -0.00002 & 0.00003 & -0.00003 & 0.00008 \\
\hline low level schooling & -0.083 & 0.058 & 0.038 & 0.031 & 0.048 & 0.054 & -0.017 & 0.025 \\
\hline middle level schooling & -0.065 & 0.052 & 0.057 & 0.047 & 0.043 & 0.051 & -0.009 & 0.034 \\
\hline contract duration $<6$ mos & 0.098 & 0.008 & 0.239 & 0.055 & 0.106 & 0.028 & 0.126 & 0.018 \\
\hline contract duration 6-12 mos & 0.012 & 0.028 & 0.024 & 0.029 & 0.010 & 0.011 & 0.015 & 0.026 \\
\hline contract duration $12-24$ mos & 0.049 & 0.038 & 0.001 & 0.060 & -0.010 & 0.022 & -0.004 & 0.027 \\
\hline contract duration $24+\operatorname{mos}$ & 0.003 & 0.026 & 0.183 & 0.093 & 0.020 & 0.060 & 0.002 & 0.022 \\
\hline regional unemployment rate & 0.004 & 0.002 & & & 0.003 & 0.003 & -0.003 & 0.002 \\
\hline log real hourly earnings & -0.035 & 0.015 & -0.012 & 0.013 & -0.026 & 0.011 & -0.067 & 0.023 \\
\hline year dummies? & \multicolumn{2}{|c|}{ yes } & \multicolumn{2}{|c|}{ yes } & \multicolumn{2}{|c|}{ yes } & & \\
\hline sample size & \multicolumn{2}{|c|}{19539} & \multicolumn{2}{|c|}{16455} & \multicolumn{2}{|c|}{14822} & \multicolumn{2}{|c|}{16578} \\
\hline
\end{tabular}

Standard errors clustered at the year level. 
Table A5: Selected individual Fixed Effects Regression Results for Search Intensity (incidence of active job search measures), Separately by Country, Women

\begin{tabular}{|c|c|c|c|c|c|c|c|c|}
\hline \multirow[t]{2}{*}{ Explanatory Variables } & \multicolumn{2}{|c|}{ Belgium } & \multicolumn{2}{|c|}{ Denmark } & \multicolumn{2}{|c|}{ Finland } & \multicolumn{2}{|c|}{ France } \\
\hline & coef & se & coef & se & coef & se & coef & se \\
\hline age & -0.011 & 0.013 & -0.001 & 0.005 & -0.025 & 0.006 & -0.007 & 0.003 \\
\hline age squared & 0.00015 & 0.00016 & -0.00004 & 0.00007 & 0.00024 & 0.00007 & 0.00004 & 0.00003 \\
\hline low level schooling & -0.060 & 0.034 & -0.014 & 0.027 & 0.024 & 0.038 & -0.231 & 0.119 \\
\hline middle level schooling & -0.024 & 0.029 & 0.019 & 0.019 & 0.022 & 0.032 & -0.060 & 0.065 \\
\hline contract duration $<6$ mos & 0.088 & 0.071 & 0.202 & 0.079 & 0.154 & 0.024 & 0.117 & 0.019 \\
\hline contract duration 6-12 mos & 0.002 & 0.041 & 0.011 & 0.033 & 0.043 & 0.027 & 0.076 & 0.016 \\
\hline contract duration $12-24$ mos & 0.039 & 0.030 & 0.023 & 0.045 & 0.003 & 0.021 & 0.071 & 0.026 \\
\hline contract duration $24+$ mos & -0.044 & 0.030 & -0.026 & 0.065 & 0.004 & 0.024 & -0.035 & 0.027 \\
\hline regional unemployment rate & 0.001 & 0.001 & & & -0.001 & 0.001 & -0.002 & 0.003 \\
\hline log real hourly earnings & -0.020 & 0.011 & 0.002 & 0.025 & -0.016 & 0.027 & 0.021 & 0.008 \\
\hline year dummies? & ye & & & & ye & & ye & \\
\hline sample size & 65 & & & & 94 & & 139 & \\
\hline \multirow[t]{2}{*}{ Explanatory Variables } & \multicolumn{2}{|c|}{ Italy } & \multicolumn{2}{|c|}{ Netherlands } & \multicolumn{2}{|c|}{ Portugal } & \multicolumn{2}{|c|}{ Spain } \\
\hline & coef & se & coef & se & coef & se & coef & se \\
\hline age & -0.014 & 0.004 & -0.009 & 0.007 & 0.001 & 0.002 & -0.021 & 0.015 \\
\hline age squared & 0.00016 & 0.00006 & 0.00014 & 0.00009 & 0.00001 & 0.00002 & 0.00012 & 0.00014 \\
\hline low level schooling & 0.050 & 0.053 & -0.021 & 0.066 & -0.025 & 0.026 & -0.062 & 0.024 \\
\hline middle level schooling & 0.017 & 0.047 & 0.023 & 0.045 & -0.017 & 0.008 & 0.001 & 0.016 \\
\hline contract duration $<6$ mos & 0.184 & 0.034 & 0.121 & 0.029 & 0.057 & 0.029 & 0.048 & 0.019 \\
\hline contract duration 6-12 mos & 0.054 & 0.015 & 0.089 & 0.071 & 0.015 & 0.013 & 0.031 & 0.022 \\
\hline contract duration $12-24$ mos & 0.074 & 0.043 & 0.028 & 0.046 & 0.061 & 0.030 & 0.021 & 0.019 \\
\hline contract duration $24+$ mos & 0.104 & 0.045 & -0.013 & 0.054 & -0.001 & 0.013 & 0.010 & 0.062 \\
\hline regional unemployment rate & 0.002 & 0.003 & & & 0.007 & 0.001 & -0.002 & 0.003 \\
\hline log real hourly earnings & -0.068 & 0.012 & -0.018 & 0.014 & -0.022 & 0.010 & -0.028 & 0.039 \\
\hline year dummies? & \multicolumn{2}{|c|}{ yes } & \multicolumn{2}{|c|}{ yes } & \multicolumn{2}{|c|}{ yes } & \multicolumn{2}{|c|}{ yes } \\
\hline sample size & \multicolumn{2}{|c|}{12633} & \multicolumn{2}{|c|}{11183} & \multicolumn{2}{|c|}{11092} & \multicolumn{2}{|c|}{9294} \\
\hline
\end{tabular}

Standard errors clustered at the year level. 